\title{
Immunohistochemical expression of Retinoblastoma gene product in normal, hyperplastic and malignant endometrium. Correlation with p53 protein expression, c-erbB-2, hormone receptors' status and proliferative activity
}

\author{
E.E. Ioachim ${ }^{\mathrm{a}, *}$, A.C. Goussia ${ }^{\mathrm{a}}$, E.G. Kitsiou ${ }^{\mathrm{b}}$, K. Charalabopoulos ${ }^{\mathrm{c}}$, E. Mermiga $^{\mathrm{b}}$ and S. Stefanaki \\ ${ }^{a}$ Dept. of Pathology, Medical School, University of Ioannina, Ioannina, Greece \\ ${ }^{\mathrm{b}}$ Dept. of Pathology, General Hospital of 'G. Hatzikosta', Ioannina, Greece \\ ${ }^{\mathrm{c}}$ Dept. of Experimental Physiology, Medical School, University of Ioannina, Ioannina, Greece
}

\begin{abstract}
Alterations of the retinoblastoma $(\mathrm{Rb})$ gene have been described in several human neoplasms and recently, it has been suggested that these alterations may play a role in the development of endometrial carcinomas. Paraffin sections from 31 cases of normal endometrium (16 proliferative, 15 secretory), 35 hyperplastic lesions and 89 endometrial carcinomas were investigated immunohistochemically for $\mathrm{Rb}$ protein $(\mathrm{pRb})$ expression. The results were compared with $\mathrm{p} 53$ and c-erbB-2 protein expression, estrogen (ER) and progesterone (PR) receptors' status and with clinicopathological prognostic factors. pRb was expressed in normal, hyperplastic and neoplastic epithelium. Proliferative endometrium showed more intense and extensive pRb staining than secretory endometrium. pRb reactivity was heterogeneous in the hyperplastic endometrial cells. Lack or focal $(<10 \%$ of endometrial cells) $\mathrm{pRb}$ immunostaining was noted in $56.2 \%$ and $27 \%$ of carcinomas, respectively. In the remaining cases $(16.8 \%) \mathrm{pRb}$ staining was heterogeneous or diffuse. The absence or presence of $\mathrm{pRb}$ expression was independent of grade and stage. In normal proliferative and secretory endometrium, $\mathrm{pRb}$ expression was correlated with $\mathrm{PR}(p=0.006$ and $p=0.001$, respectively), PCNA ( $p=0.04$ and $p=0.01$, respectively) and MIB1 ( $p=0.02$ and $p<0.0001$, respectively) expression. In hyperplasias, $\mathrm{pRb}$ was related to PR $(p=0.016)$ and MIB1 $(p<0.0001)$ expression. In carcinomas, a relationship of $\mathrm{pRb}$ expression with $\mathrm{p} 53(p=0.0015)$, ER $(p=0.0002), \mathrm{PR}(p=0.0004)$ and PCNA $(p=0.013)$ status was detected. We suggest that the absence or presence of $\mathrm{pRb}$ expression does not seem to be associated with the progression of endometrioid carcinoma. In addition, $\mathrm{pRb}$ seems to be normally regulated in relation to the proliferative growth fraction of the tumours.
\end{abstract}

Keywords: Rb, p53, hormone receptors, MIB-1, PCNA, endometrial carcinoma

\section{Introduction}

Endometrial carcinoma is the most common malignant neoplasm of the female genital tract. Despite its

*Address for correspondence: Dr Elli Ioachim, Department of Pathology, Medical School, University of Ioannina, 45110 Ioannina, Greece. Tel./Fax: +30 651 99212; E-mail: ioachime@otenet.gr. relative frequency, the understanding of the molecular events that contribute to the development and progression of this type of cancer remains poorly understood.

At the molecular genetic level, a series of changes initiate and promote the progression towards the malignant phenotype. These changes can be subdivided into discrete steps, involving activation of oncogenes and inactivation of tumour suppressor genes, which in 
their totality contribute to the tumorigenic process. The most common targets for genetic alteration across all types of human cancer are the tumour suppressor genes $\mathrm{Rb}$ and $\mathrm{p} 53$.

Understanding the role that $\mathrm{Rb}$ and $\mathrm{p} 53$ genes play in human cancer, as well as their normal biochemical function in growth control, has been the subject of recent studies. Allelic losses or mutations of these genes can occur either early or late in malignant progression, depending on tumour type $[6,8,40,42]$. Whereas p53 gene mutations often result in the abnormal nuclear accumulation of the altered protein [13], the majority of reported $\mathrm{Rb}$ mutations correspond to loss or reduced expression of the protein $[15,16,26,37,42]$; in a relatively small percentage of the cases a nuclear reactivity may be observed even in the presence of a mutation [33]. Moreover, it has been suggested that alteration in both $\mathrm{p} 53$ and $\mathrm{Rb}$ genes may have cooperative tumorigenic effects in mice [41] or may act in a synergistic or cooperative way to promote tumour progression in human cancer [9].

Recently, abnormalities of the Rb gene have been reported to contribute to the development of endometrial cancer, but the existing studies are relatively few and with conflicting results. Immunohistochemical $\mathrm{pRb}$ expression has been detected in the majority of endometrial cancer cases studied [30,31,33]. Analysis of the $\mathrm{Rb}$ gene in endometrial carcinoma cell lines and endometrial tumour tissue has shown that $\mathrm{Rb}$ mutation or loss of heterozygosity are rare events in these tumours $[12,35,43]$.

Alterations of the p53 gene have been shown to be among the most common molecular biologic changes in endometrial cancer $[1,23,34]$. P53 protein overexpression has been associated with high histological grade, extensive myometrial invasion and lymph node metastases [18,19,28].

Overexpression of c-erbB-2 protein is a frequent and prognostically relevant event in a variety of human cancers. In tumours of hormonally sensitive tissues, such as endometrial carcinoma, c-erbB-2 protein expression has been correlated with advanced stage disease [4,20, 27] even though no correlation with stage or histologic grade has also been reported [19].

In the present study we examined the immunohistochemical expression of $\mathrm{pRb}$ in normal, hyperplastic, and neoplastic epithelium in order to investigate its role in endometrial cancer development and progression. In addition, the correlation of $\mathrm{pRb}$ with traditional clinicopathological prognostic factors as well as with markers of potential prognostic value such as p53, c-erbB-2, hormone receptors (ER, PR) and proliferation associated indices (MIB-1, PCNA) has also been examined.

\section{Materials and methods}

We examined 60 surgical specimens from patients with endometrial carcinoma. All women underwent a total abdominal hysterectomy/bilateral salpingooophorectomy and none received preoperative pelvic radiation. In addition, samples of curetting adenocarcinoma ( $n=29)$, hyperplasias $(n=35)$ and normal endometrium ( $n=31$ : 16 proliferative, 15 secretory) were also studied. Histologically, all carcinomas were classified as endometrioid-type and in each case using standard hematoxylin and eosin (H\&E) morphologic examination we evaluated the following parameters: the nuclear and architectural grade, the mitotic activity expressed as the number of mitotic figures per 10 high-power fields (HPF), the presence of vessel invasion and squamous differentiation. Histologic grading and surgical staging was based on the revised FIGO criteria [14].

\subsection{Immunohistochemistry}

Immunohistochemistry on one or two selected blocks from each case was performed on $4 \mu \mathrm{m}$ tissue sections using avidin-biotin complex immunoperoxidase method. To unmask the epitopes of $\mathrm{pRb}, \mathrm{p} 53$, c-erbB-2 and MIB1, we microwaved the sections in $10 \mathrm{mM}$ citrate buffer, $\mathrm{pH}=6.0$. ER, PR and PCNA unmasking was achieved without using the heat mediated antigen retrieval method. Subsequently, the sections were treated with 0.3 per cent hydrogen peroxide $\left(\mathrm{H}_{2} \mathrm{O}_{2}\right.$ in methanol) for 30 min to block endogenous peroxidase and then incubated with primary antibodies. The slides were counterstained in hematoxylin, dehydrated and mounted.

To assess the specificity of the reaction positive and negative control slides were used in each run. Positive controls were consisted of breast cancer tissues known to be positive for c-erbB-2, ER, PR and colon cancer tissue known to be positive for p53. Tissue sections subjected to the whole procedure expect for incubation with the primary antibody were used as "negative" substitute. All controls gave satisfactory results.

The sources and dilution of the antibodies are shown in Table 1.

\subsection{Immunohistochemical evaluation}

The immunoreactivity was interpreted by lightmicroscopic examination and evaluated independently by two observers. The staining was evaluated in the 
Table 1

Antibodies used

\begin{tabular}{llll}
\hline Antibodies & Supplier & Dilution & Incubation time \\
\hline Rb (AB-5) & Oncogene & $1: 80$ & Overnight* \\
p53 (DO-7, IgG2b) & Ylem & $1: 200$ & One hour* \\
C-erbB-2 (OM-11-925) & ICI, Cambridge & $1: 500$ & One hour* \\
ER & Dako & $1: 50$ & One hour \\
PR & Dako & $1: 75$ & One hour \\
PC-10 & Dako & $1: 50$ & One hour \\
MIB1 (Ki-67 paraffin) & Ylem & $1: 10$ & Overnight* \\
\hline
\end{tabular}

* With microwave oven antigen retrieval.

areas with well-preserved tissue morphology and away from artifacts. Each sample was first scanned with a low magnification, and at least 10 fields were assessed with a high-power magnification.

We considered tissue samples as having a positive $\mathrm{pRb}$ phenotype only when pure nuclear staining was demonstrated. A weak concomitant cytoplasmic staining occasionally observed in some sections was probably nonspecific and therefore was not analysed. In all cases there were normal cells such as stromal (fibroblasts), inflammatory (lymphocytes) and endothelial cells that displayed $\mathrm{pRb}$ staining. These cells were used as an internal positive control in order to interpret $\mathrm{pRb}$ immunoreactivity.

Cases were scored as $\mathrm{pRb}$ negative if no nuclear staining of endometrial cells or focal staining $(<10 \%$ of cells) was observed and contiguous $\mathrm{pRb}$ positive control cells were present. Cases were scored as $\mathrm{pRb}$ positive if nuclear staining was heterogeneous ( $>10 \%$ of positive endometrial cells) or diffuse. Some $\mathrm{pRb}$ positive cases with diffuse staining demonstrated strong staining in more than $>70 \%$ of the epithelial cells but because these cases were relatively few they were not separated into a distinct group.

Based on other studies, only cases showing staining at least $10 \%$ of endometrial cell nuclei were considered to be $\mathrm{p} 53$ positive $[39,45]$. c-erbB-2 protein immunoreactivity was scored as negative $(<25 \%$ of positive endometrial cells) and positive ( $>25 \%$ of positive endometrial cells). Only intense membrane immunostaining was accepted as positive for the protein, since it has been shown to yield the best prognostic associations [11]. Cases exhibited ER and PR nuclear staining in more than $5 \%$ of endometrial cells were regarded as positive [34]. Only nuclear epithelial staining was considered positive for MIB-1 and PCNA expression and for statistical analysis the cases were divided into groups using a semiquantitative approach; into two groups for MIB1 ( $<10 \%,>10 \%$ of positive cells) and into three groups for PCNA $(<10 \%, 10-50 \%,>50 \%$ of positive cells). These subcategories were chosen after it was observed that the cases were divided into nearly equal groups.

\subsection{Statistical analysis}

The data were entered into a microcomputer and statistical analysis was performed using SPSS statistical package. The association of continuous variables was confirmed using a nonparametric test for two independent samples (Mann-Whitney U test) or regression analysis. The level of significance was defined as $p<0.05$.

\section{Results}

The staining pattern of $\mathrm{pRb}$ expression in normal, hyperplastic and malignant cases is shown in Figs 1 through 4.

In normal proliferative endometrium a strong $\mathrm{pRb}$ staining in most of the endometrial cells was observed in $6 / 16(37.5 \%)$ of cases, while only $1 / 15(6.75 \%)$ case of secretory endometrium exhibited nuclear staining in a few cells. In addition, 12/35 (34.3\%) cases of the hyperplastic lesions displayed $\mathrm{pRb}$ positivity in a more heterogeneous pattern with various staining intensity from cell to cell. Loss or focal $\mathrm{pRb}$ expression was found in 50/89 (56.2\%) and 24/89 (27\%) cases of carcinomas respectively (total number of $\mathrm{pRb}$ negative cases $74 / 89 ; 83.2 \%)$. A heterogeneous or diffuse pRb immunostaining was detected in $15 / 89(16.8 \%)$ tumours. In cases with diffuse pattern of $\mathrm{pRb}$ reactivity, the staining was more intense and was detected in the majority of endometrial cells ( $>70 \%$ of cells). The results of $\mathrm{pRb}$ immunoreactivity in normal, hyperplastic and malignant endometrium are shown in Fig. 5.

P53 protein expression was not detected in normal and hyperplastic endometrium but high expression of the protein was detected in 15/87 (17.2\%) of carcinomas. Normal and hyperplastic endometrium showed low or absent c-erbB-2 protein expression and 10/85 


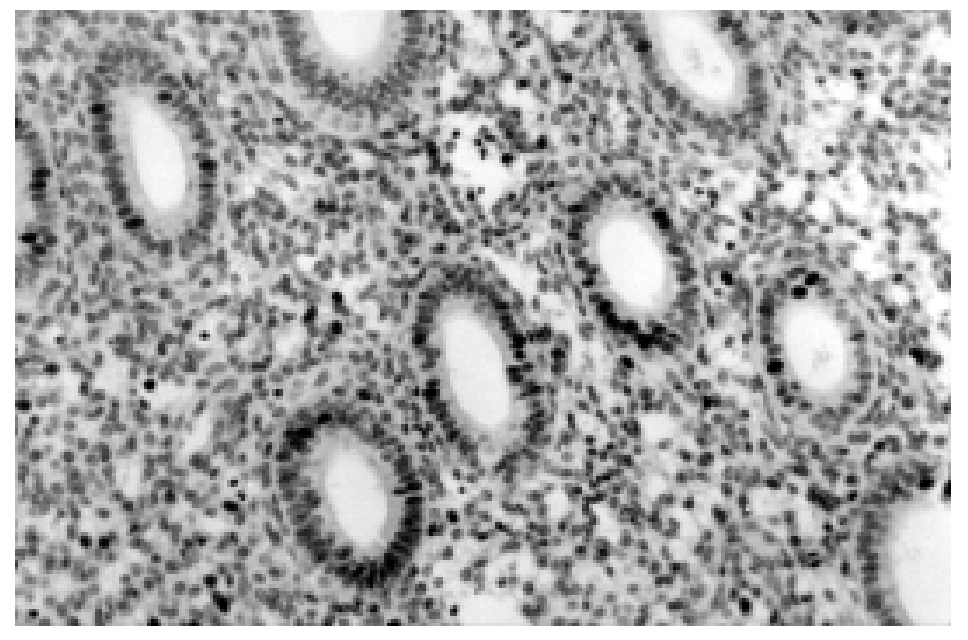

Fig. 1. Normal proliferative endometrium showing strong and extensive pRb nuclear reactivity (ABC; original magnification, 200X).

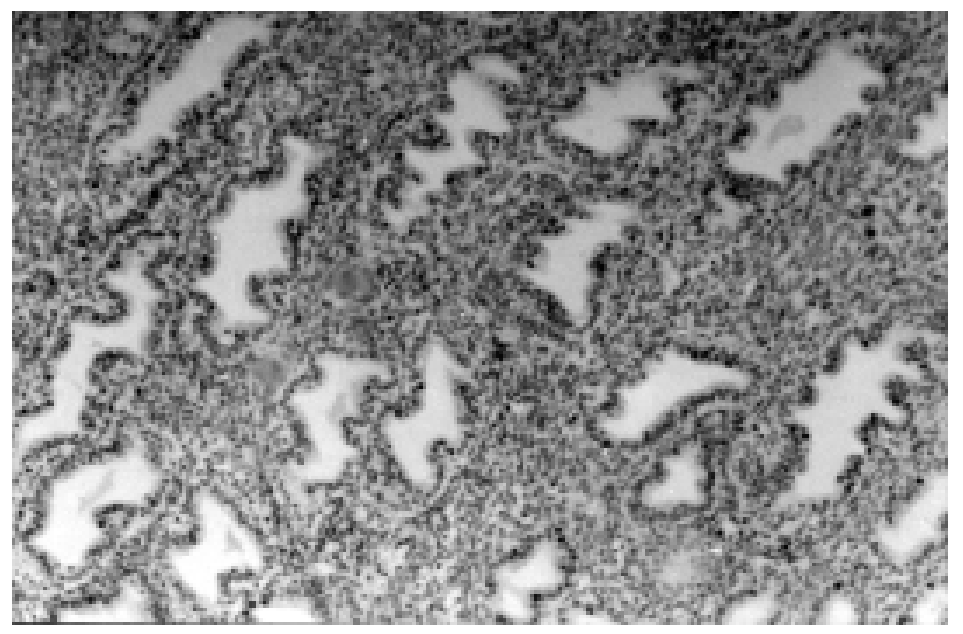

Fig. 2. Normal secretory endometrium showing faint to absent nuclear immunostaining for $\mathrm{pRb}$ (ABC; original magnification, 100X).

(11.8\%) cases of carcinomas demonstrated expression of the protein in $>25 \%$ of neoplastic cells.

Positive ER and PR expression ( $>10 \%$ of epithelial cells) was detected in $94.1 \%$ and $76.5 \%$ of cases of proliferative endometrium respectively, while in secretory endometrium ER and PR expression was observed in $7.1 \%$ and $6.7 \%$ of the cases respectively. In hyperplastic lesions, ER and PR expression was found in $32 / 35(91.4 \%)$ and 25/35 (71.4\%) of the cases respectively. The endometrioid carcinomas displayed ER and PR immunoreactivity in $22.2 \%$ and $20.9 \%$ of the cases respectively. The statistical analysis revealed that in proliferative and secretory endometrium, $\mathrm{pRb}$ expression was correlated with $\mathrm{PR}(p=0.006$ and $p=0.001$, respectively), MIB1 ( $p=0.02$ and $p<0.0001$, respectively) and PCNA ( $p=0.04$ and $p=0.01$, respec- tively) expression. In hyperplastic lesions, $\mathrm{pRb}$ expression was correlated with PR $(p=0.016)$ and MIB1 $(p<0.0001)$ expression. In the cases of carcinomas, we found no correlation of $\mathrm{pRb}$ absence or presence with tumour grade, stage and other conventional clinicopathological parameters studied (Table 2). A positive relationship of $\mathrm{pRb}$ expression with $\mathrm{p} 53(p=0.0015)$, ER $(p=0.0002), \operatorname{PR}(p=0.0004)$ and PCNA ( $p=$ 0.013 ) expression was observed (Table 3 ).

In the group of carcinomas, the statistical analysis of the other studied markers showed that p53 protein overexpression was related to histologic grade ( $p=$ $0.0001)$ and stage $(p=0.02)$, PCNA $(p=0.0005)$ and MIB1 ( $p=0.003)$ score and inversely to ER ( $p=$ 0.04 ) content. Additionally, the overexpression of $c-$ erbB-2 protein was correlated with tumour grade ( $p=$ 


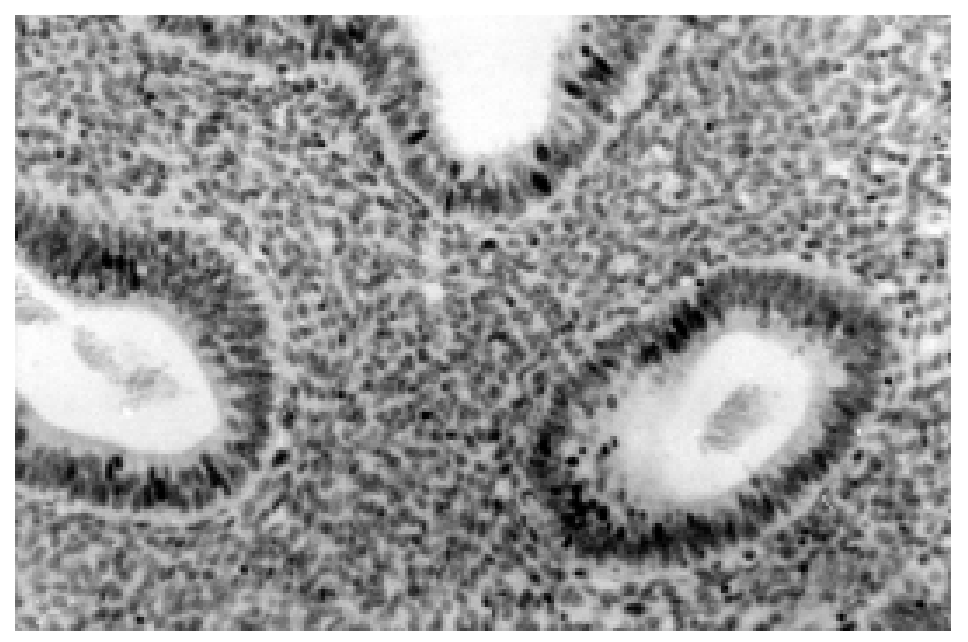

Fig. 3. Endometrial hyperplasia. Heterogeneous immunoreactivity for pRb in epithelial cells (ABC; original magnification, 400X).

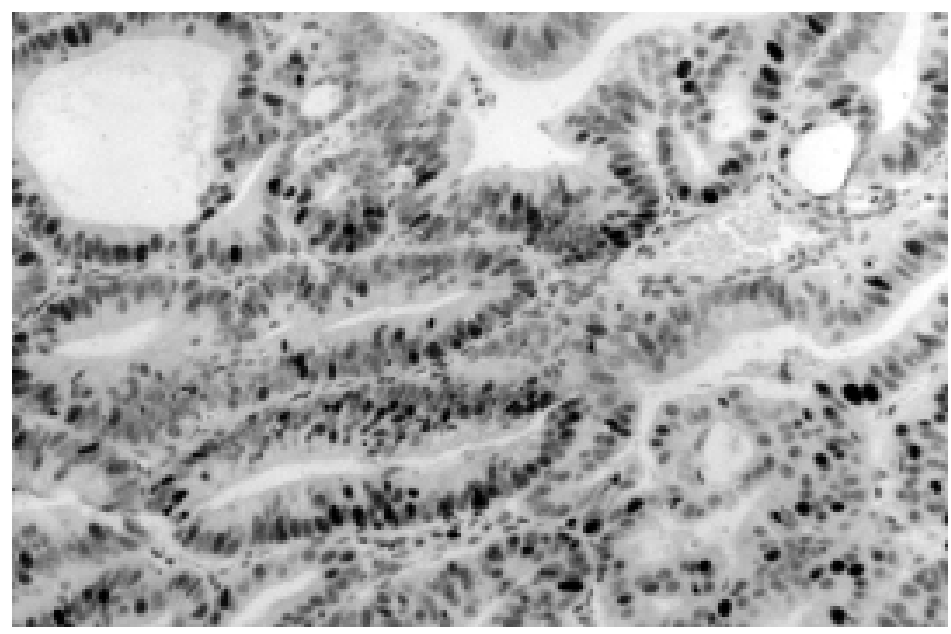

Fig. 4. A case of a well differentiated endometrial adenocarcinoma showing strong and diffuse pRb expression (ABC; original magnification, 200X).

$0.01)$, PCNA ( $p=0.002)$ and MIB-1 $(p=0.005)$ expression. MIB1 and PCNA expression was statistically related to tumour grade $(p=0.0007$ and $p=0.0004$ respectively).

\section{Discussion}

The detection of abnormalities of the $\mathrm{Rb}$ gene has been demonstrated in a significant proportion of human primary tumours and derived cell lines. While the primary methods for detected alterations in $\mathrm{Rb}$ are genetic, it has now been demonstrated that alterations in the gene can also be detected by analysis of its gene product. Immunohistochemical analysis studies have used the loss or the greatly reduced levels of $\mathrm{pRb}$ protein expression as the criterion for scoring a tumour as having $\mathrm{Rb}$ gene alterations $[15,16,26,37,42]$. However, in other studies high levels of $\mathrm{pRb}$ expression has been suggested to reflect a dysfunctional $\mathrm{Rb}$ pathway $[9,17]$.

Molecular methods which are guided to the analysis of $\mathrm{Rb}$ gene expression are more sensitive techniques in detecting underlying $\mathrm{Rb}$ alterations. Immunohistochemistry has been considered as an alternative technique but its utilization has some limitations. This method allows identifying the degree of heterogeneity as well as the degree of staining intensity within a tissue. However, a weak staining is sometimes difficult to evaluate and cases that are characterized as $\mathrm{pRb}$ negative, in fact express the protein but in low levels. 


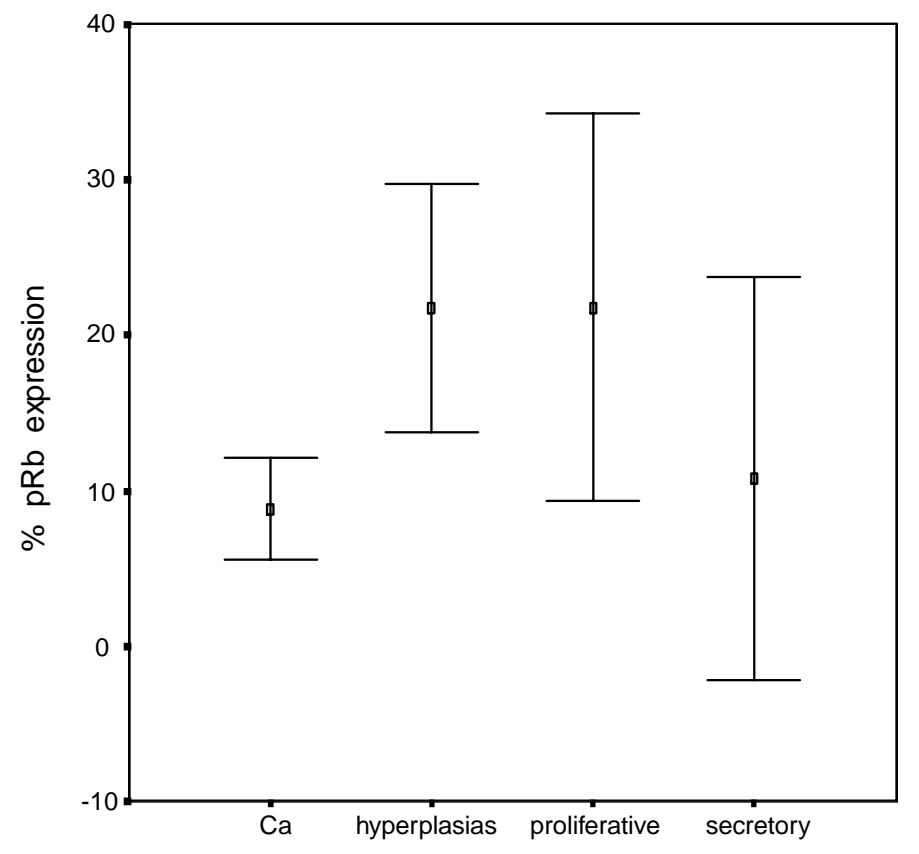

Fig. 5. pRb immunoexpression in normal, hyperplastic and malignant endometrium.

In addition, a definite $\mathrm{pRb}$ staining is rarely observed even in the presence of mutation [33]. A heterogeneous pattern must be estimated with caution. It may be due to the presence of two distinct tumour clones, one having the normal protein and another harboring a mutation. It also may reflect cell cycle differences in $\mathrm{pRb}$ expression or its degree of phosphorylation. It may also be related to the differences in the level of bound and unbound $\mathrm{pRb}$. For this latter issue appropriate antibodies that detect both hypophosphorylated and hyperphosphorylated protein need to be used. Finally, as a general comment, the appropriate fixation of the tissue as well as the utilization of positive and negative controls are necessary for the accurate evaluation of immunohistochemical procedure.

To our knowledge, there are relatively few studies related with the examination of $\mathrm{Rb}$ alterations in endometrial lesions. Using Southern blot hybridization, Sassano et al. did not find any abnormalities of the $\mathrm{Rb}$ gene in cases of endometrial hyperplasia and endometrial carcinomas, whereas a homozygous deletion of the gene was found in a case of endometrioid tumour of the ovary [35]. By polymerase chain reaction-restriction fragment length polymorphism analysis, Enomoto et al reported loss of heterozygosity of the $\mathrm{Rb}$ gene in some cases of endometrial carcinomas [12]. Similarly, by polymerase chain reaction and sequencing analysis, Rb gene abnormalities was observed in some cases of human endometrial carcinoma tissues and endometrial carcinoma cell lines suggested that Rb gene abnormalities may be involved in endometrial carcinogenesis [43].

By immunohistochemical approach, pRb expression was identified in normal, hyperplastic and malignant endometrium $[1,31,33,36]$ and in some studies an altered expression of the protein especially in high grade and advanced endometrial tumours have been reported [33,36]. Niemann et al. [33] taking account the staining intensity of $\mathrm{pRb}$ have reported a strong nuclear staining in the majority of epithelial cells in $10 / 10$ cases of proliferative endometrium and a weak or absent expression in the epithelial cells of secretory endometrium. The authors have also found a more heterogeneous pattern of $\mathrm{pRb}$ reactivity with various nuclear staining in all cases of hyperplasia and in the majority of carcinomas. An altered expression of the protein, determined by the presence of heterogeneous staining and of large negative areas, has been observed in a subset of high grade carcinomas. Milde-Langosch et al. [31] have reported pRb reactivity in most normal, hyperplastic and neoplastic endometrial cases studied with the strongest staining intensity observed in proliferative endometrium. In their neoplastic cases, $\mathrm{pRb}$ expression was not correlated with histologic grade and FIGO stage. Ambros et al. [1] using a computerized image analysis system for $\mathrm{pRb}$ evaluation did not find 
Table 2

Correlation of $\mathrm{pRb}$ expression with clinicopathological features in endometrial carcinomas

\begin{tabular}{lrrrr}
\hline & \multicolumn{3}{c}{ pRb expression } & \multirow{2}{*}{ p value } \\
\cline { 2 - 3 } & $(-)$ & $<10 \%$ & $>10 \%$ & \\
\hline Age & 3 & 2 & & NS \\
$\quad<45$ & 10 & 6 & 3 & \\
$45-55$ & 36 & 11 & 11 & \\
$>55$ & & & & \\
Grade & 17 & 5 & 4 & NS \\
1 & 23 & 12 & 5 & \\
2 & 12 & 4 & 6 & \\
3 & & & & \\
Stage & 28 & 9 & 5 & NS \\
I & 8 & 3 & & \\
II & 6 & 1 & 1 & \\
III & 2 & 1 & & \\
IV & & & & \\
Vessels invasion & 27 & 11 & 4 & NS \\
$\quad(-)$ & 15 & 3 & 2 & \\
$\quad(+)$ & & & & \\
Squamous Metaplasia & 42 & 18 & 15 & NS \\
$\quad(-)$ & 9 & 3 & & \\
$\quad(+)$ & & &
\end{tabular}

any difference of $\mathrm{pRb}$ expression in normal and neoplastic endometrium.

In the present study, the comparison of normal endometria, hyperplasias and endometriod carcinomas showed that $\mathrm{pRb}$ was expressed in all endometrial lesions. In normal endometria, immunoreactivity was observed predominantly in proliferative endometrium than in secretory endometrium and in the most of proliferating epithelial cells. This observation is in accordance with the findings of previous studies [31,33].

Negative $\mathrm{pRb}$ expression was observed in most of carcinomas studied and in the remaining cases a positive $\mathrm{pRb}$ reactivity was observed. Neither the $\mathrm{pRb}$ loss nor the expression of the protein showed any significant correlation with tumour grade or FIGO stage, suggesting that in our cases $\mathrm{Rb}$ status does not seem to be associated with the progression of the malignant processs.

However, a statistically significant correlation was observed between $\mathrm{pRb}$ expression and $\mathrm{p} 53$ overexpression. Alterations to the human p53 gene either in the form of gene loss or mutations have been observed to be a common change in endometrial carcinomas related to tumour development and progression [1,23, 34]. Immunohistochemical overexpression of p53 has also been reported to be correlated with high grade and advanced tumours $[18,19,28,44]$, as well as with decreased patient survival $[18,38,39]$. In the current study, the absence of p53 expression in either normal or hyperplastic endometrium is comparable to the findings of previous studies $[29,30]$. Of carcinomas, only
Table 3

Correlation of $\mathrm{pRb}$ expression with potential prognostic markers in endometrial carcinomas

\begin{tabular}{|c|c|c|c|c|}
\hline & \multicolumn{3}{|c|}{$\mathrm{pRb}$ expression } & \multirow[t]{2}{*}{$\mathrm{p}$ value } \\
\hline & $(-)$ & $<10 \%$ & $>10 \%$ & \\
\hline \multicolumn{5}{|l|}{$p 53$} \\
\hline$<10$ & 46 & 20 & 10 & \multirow[t]{2}{*}{$p=0.0015$} \\
\hline$>10$ & 5 & 1 & 6 & \\
\hline \multicolumn{5}{|c|}{$c-e r b B-2$} \\
\hline$<25$ & 47 & 17 & 11 & \multirow[t]{2}{*}{ NS } \\
\hline$>25$ & 5 & 3 & 3 & \\
\hline \multicolumn{5}{|l|}{$E R$} \\
\hline$<5$ & 39 & 10 & \multicolumn{2}{|l|}{$8 p=0.0002$} \\
\hline$>5$ & 9 & 7 & 1 & \\
\hline \multicolumn{5}{|l|}{$P R$} \\
\hline$<5$ & 46 & 14 & 8 & \multirow[t]{2}{*}{$p=0.0004$} \\
\hline$<5$ & 6 & 7 & 5 & \\
\hline \multicolumn{5}{|l|}{$M I B 1$} \\
\hline$<10$ & 49 & 15 & 12 & \multirow[t]{2}{*}{ NS } \\
\hline$>10$ & 4 & 6 & 3 & \\
\hline \multicolumn{5}{|l|}{ PCNA } \\
\hline$<10$ & 30 & 7 & 2 & \multirow[t]{3}{*}{$p=0.013$} \\
\hline $10-50$ & 15 & 8 & 6 & \\
\hline$>50$ & 8 & 6 & 7 & \\
\hline
\end{tabular}

$17.2 \%$ cases were scored as positive for p53 and all these tumours were of high grade, with high proliferative activity and with no or minimal reactivity for ER or PR. Furthermore, tumours showing p53 overexpression exhibited $\mathrm{pRb}$ expression. In the extensive study of Li et al. [30] endometriod carcinoma cells without or with faint p53 staining were usually strongly positive for $\mathrm{pRb}$. In other studies no correlation between $\mathrm{pRb}$ and p53 expression has been found [5,21,32]. It has been reported that mutation of p53 gene in endometrial carcinomas has been associated with $\mathrm{p} 53$ protein overexpression [27]. Although anti-p53 antibodies, theoretically, bind to both the mutated and wild types of p53 protein, a positive expression often reflects a genetic mutation [3]. This could be partly explained by the relatively short half-life of the wild-type protein. In our p53 positive cases probably the observed p53 expression does not reflect an alteration of the gene and therefore, under this aspect, the positive correlation of p53 and $\mathrm{pRb}$ can be explained. An alternative hypothesis is that, the strong and diffuse staining pattern that was observed in a subset of $\mathrm{pRb}$ positive carcinomas, which we didn't study separately, like in bladder cancer [9], may reflect an abnormal $\mathrm{Rb}$ status. Thus, abnormalities in p53 and $\mathrm{Rb}$ genes resulting in overexpression of both $\mathrm{p} 53$ and $\mathrm{Rb}$ proteins may be observed in a portion of tumours probably, with a more aggressive phenotype. However, this issue definitely requires further investigation.

Overexpression of the c-erbB-2 oncogene product has been found to occur in a proportion of endometrial 
carcinomas and according to some studies it has been associated with a more aggressive tumour phenotype [4, $20,27]$. In our study a relationship of c-erbB-2 expression with histologic grade and the proliferative growth fraction of the tumours has been found. The correlation between c-erbB-2 and $\mathrm{pRb}$ was insignificant.

The results of the present study showed that in endometrial lesions $\mathrm{pRb}$ expression was correlated with ER and /or PR expression. Endometrial tissue is considered to be a sex steroid-dependent tissue and immunohistochemical analysis studies have reported expression of hormone receptors in normal, hyperplastic and neoplastic endometrium $[10,30]$. The negative expression of ER and PR in endometrial carcinomas has been found to be associated with tumour grade, advanced clinical stage and unfavorable patient prognosis $[10,44]$. According to the findings of other investigators [30] we observed that the glandular cells of the normal proliferative endometrium exhibited positive expression of ER and PR in the majority of the cases, whereas downexpression of the receptors was found in the glandular cells of the secretory endometrium. A high proportion of hyperplastic lesions and some cases of carcinomas were also positive for ER and PR. The relationship between positive expression of ER/PR and positive $\mathrm{pRb}$ expression was a notable observation which probably means, that a subset of endometrioid carcinomas related to hormone stimulations is not associated with $\mathrm{Rb}$ gene loss or inactivation.

The endometrium is an actively proliferating tissue and there is an overlap in cell proliferation fraction between benign endometrium and endometrial carcinoma [22]. Previous studies of proliferation markers in endometrial carcinomas have obtained conflicting results regarding their usefulness in predicting prognosis. Determination of Ki-67 index in a series of normal, hyperplastic and malignant endometrial lesions showed no evidence of correlation with progression to malignancy [22]. High PCNA index has been associated with advanced cancer stage, myometrial invasion and c-erbB-2 expression [19]. In our study, the increased expression of proliferation markers was correlated with tumour grade. In addition, the proliferative activity as determined by Ki-67 and PCNA was paralleled with $\mathrm{pRb}$ expression in both malignant and no malignant tissues. A relation between $\mathrm{pRb}$ expression and proliferative activity has also been reported in lymphoid tissue, in lymphomas and breast carcinomas [5, $7,24]$. This finding probably means that in some cases of endometrioid carcinomas $\mathrm{pRb}$ behaves normally in regulating the cell cycle.
In conclusion, we suggest that the absence or presence of $\mathrm{pRb}$ expression does not seem to be associated with the progression of endometrioid carcinomas. In addition, $\mathrm{pRb}$ is normally regulated in relation to the proliferative activity of the tumours. On the other hand, there is probably a subset of tumours, in which abnormalities of p53 and Rb may act in a synergistic way, resulting in a more aggressive phenotype. This is an important issue and the topic of future research.

\section{Acknowledgement}

We thank Mrs Antigoni Christodoulou for the technical assistance.

\section{References}

[1] R.A. Ambros, P.A. Vigna, J. Figge, B.V.S. Lallakury, A. Mastrangelo, A.Y. Eastamn, J. Malfetano, H.L. Figge and J.S. Ross, Observations on tumor and metastatic gene status in endometrial carcinoma with particular emphasis on p53, Cancer 73 (1994), 1686-1692.

[2] A. Ayhan, Z.S. Tuncer, S. Ruacan, A. Ayhan, W. Yasui and E. Tahara, Abnormal expression of cripto and p53 protein in endometrial carcinoma and its precursor lesions, Eur J Gynecol Oncol 19 (1998), 316-318.

[3] L.Banks, G. Matlashewski and L. Crawford, Isolation of human p53 specific monoclonal antibodies and their use in the studies of human p53 expression, Eur J Biochem 159 (1986), 529-534.

[4] A. Berchuck, G. Rodriguez, R.B. Kinney, J.T. Soper, R.K. Dodge, D.L. Clarke-Pearson and R.C. Jr. Bast, Overexpression of her-2/neu in endometrial cancer is associated with advanced stage disease, Am J Obstet Gynecol 164 (1991), 15-21.

[5] C. Ceccarelli, D. Santini, P. Chieco, M. Taffurelli, M. Gamberini, S.A. Pileri and D. Marrano, Retinoblastoma (RB1) gene product expression in breast carcinoma. Correlation with Ki-67 growth fraction and biopathological profile, J Clin Pathol 51 (1998), 818-824.

[6] C. Cordon-Cardo, Mutation of cell cycle regulators. Biological and clinical implications for human neoplasia, Am J Pathol 147 (1995), 545-560.

[7] C. Cordon-Cardo and V.M. Richon, Expression of the retinoblastoma protein is regulated in normal human tissues, Am J Pathol 144 (1994), 500-510.

[8] C. Cordon-Cardo, D. Wartinger, D. Petrylak, G. Dalbagni, W.R. Fair, Z. Fuks and V.E. Reuter, Atered expression of the retinoblastoma gene product: prognostic indicator in bladder cancer, J Natl Cancer Inst 84 (1992), 1251-1256.

[9] R.J. Cote, M.D. Dunn, S.J. Chatterjee, J.P. Stein, S.R. Shi, Q.C. Tran, S.X. Hu, S. Groshen, C.R. Taylor, D.G. Skinner and W.F. Benedict, Elevated and absent $\mathrm{pRb}$ expression is associated with bladder cancer progression and has cooperative effects with p53, Cancer Res 58 (1998), 1090-1094.

[10] W.T. Creasman, Prognostic significance of hormone receptors in endometrial cancer, Cancer 71 (1993), 1467-1470. 
[11] C.R. De Potter, C. Beghin, A.P. Makar, D. Vandekerckhove and H.J. Roel, The neu-oncogene protein as a predictive factor for haematogenous metastases in breast cancer patients, Int $J$ Cancer 45 (1990), 55-58.

[12] T. Enomoto, M. Fujita, M. Inoue, A. Nakazawa-Miyamoto, O. Tanizawa and T. Nomura, Alterations of the Rb gene and its association with Ki-ras activation and p53 inactivation in endometrial adenocarcinoma, Mol Carcinogen 8 (1993), 132137.

[13] D. Esrig, C.H. III. Spruck, P.W. Nichols, B. Chaiwun, K. Steven, S. Groshen, S.-C. Chen, D.G. Skinner, P.A. Jones and R.C. Cote, p53 nuclear protein accumulation correlates with mutations in the p53 gene, tumor grade, and stage in bladder cancer, Am J Pathol 143 (1993), 1389-1397.

[14] FIGO stages-1988 revisions, Gynecol Oncol 35 (1989), 125127.

[15] J. Geradts, R.A. Kratzke, S. Crush-Stanton, S.F. Wen and C.E. Lincoln, Wild-type and mutant retinoblastoma protein in paraffin sections, Mod Pathol 9 (1996), 339-347.

[16] E. Gras, C. Pons, P. Machin, X. Matias-Guiu and J. Prat, Loss of heterozygosity at the RB-1 locus and pRb immunostaining in epithelial ovarian tumour: a molecular, immunohistochemical, and clinicopathologic study, Int J Gynecol Pathol 20 (2001), 335-340.

[17] H.B. Grossman, M. Liebert, M. Antelo, C.P.N. Dinney, S.-X. Hu, J.L. Palmer and W.F. Benedict, p53 and RB expression predict progression in T1 bladder cancer, Clin Cancer Res 4 (1998), 829-834

[18] N.W. Hamel, T.J. Sebo, T.O. Wilson, G.L. Keeney, P.C. Roche, V.J. Suman, T.C. Hu and K.C. Podratz, Prognostic value of p53 and proliferating cell nuclear antigen expression in endometrial carcinoma, Gynecol Oncol 62 (1996), 192-198.

[19] H.M. Heffner, A.N. Freedman, J.E. Asirwatham and S.B. Lele, Prognostic significance of p53, PCNA, and c-erbB-2 in endometrial adenocarcinoma, Eur J Gynecol Oncol 20 (1999), 8-12.

[20] D.J. Hetzel, T.O. Wilson, G.L. Keeney, P.C. Roche, S.S. Cha and K.C. Podratz, HER-2/neu expression: a major prognostic factor in endometrial cancer, Gynecol Oncol 47 (1992), 179185.

[21] E. Ioachim, A. Charchanti, N.E. Stavropoulos, A. Skopelitou, E.D. Athanassiou and N.J. Agnantis, Immunohistochemical expression of Retinoblastoma gene product $(\mathrm{Rb}), \mathrm{p} 53$ protein, MDM2, c-erbB-2, HLA-DR and proliferation indices in human urinary bladder carcinoma, Histol Histopathol 15 (2000), 721-727.

[22] O.B. Ioffe, J.C. Papadimitriou and C.B. Drachenberg, Correlation of proliferation indices, apoptosis, and related oncogene expression (bcl-2 and c-erbB-2) and p53 in proliferative, hyperplastic, and malignant endometrium, Hum Pathol 29 (1998), 1150-1159.

[23] K. Ito, H. Sasano, G. Matsunaga, S. Sato, A. Yajima, S. Nasim and C.T. Garret, Correlation between p21 expression and clinicopathological findings, p53 gene and protein alterations, and survival in patients with endometrial carcinoma, J Pathol 183 (1997), 318-324.

[24] P. Jares, E. Campo, M. Pinyol, F. Bosch, R. Miquel, P.L. Fernandez, M. Sanchez-Beato, F. Soler, A. Perez-Losada, I. Nayach, C. Mallofre, M.A. Piris, E. Montserrat and A. Cardesa, Expression of Retinoblastoma Gene Product (pRb) in Mantle Cell Lymphomas. Correlation with Cyclin D1 (PRAD1/CCND1) mRNA Levels and Proliferative Activity, Am J Pathol 148 (1996), 1591-1600.
[25] D. Johnson, J.K. Schwarz, W.D. Cress and J.R. Nevins, Expression of transcription factor E2F1 induces quiescent cells to enter S phase, Nature 365 (1993), 349-352.

[26] F.J. Kaye, R.A. Kratzke, J.L. Gerster and J.M. Horowitz, A single amino acid substitution results in a retinoblastoma protein defective in phosphorylation and oncoprotein binding, Proc Natl Acad Sci USA 87 (1990), 6922.

[27] M.A. Khalifa, R.S. Mannel, S.D. Haraway, J. Walker and K.W. Min, Expression of EGFR, HER-2/neu, p53, and PCNA in endometrioid, serous papillary and clear cell endometrial adenocarcinomas, Gynecol Oncol 53 (1994), 84-92.

[28] M.F. Kohler, A. Berchuck, A.M. Davidoff, P.A. Humphrey, R.K. Dodge, J.D. Iglehart, J.T. Soper, D.L. Clarke-Pearson, R.C. Bast and J.R. Marks, Overexpression and mutation of p53 in endometrial carcinoma, Cancer Res 52 (1992), 1622-1627.

[29] M.F. Kohler, H. Nishii and P.A. Humphrey, Mutation of the p53 tumour suppressor gene is not a feature of endometrial hyperplasia, Am J Obstet Gynecol 169 (1993), 690-694.

[30] S.-F. Li, T. Shiozawa, K. Nakayama, T. Nikaido and S. Fujii, Stepwise abnormality of sex steroid hormone receptors, tumor suppressor gene products (p53 and Rb), and cyclin E in uterine endometriod carcinoma, Cancer 77 (1996), 321-329.

[31] K. Milde-Langosch, L. Riethdorf, A.-M. Bamberger and T. Loning, P16/MTS1 and pRb expression in endometrial carcinomas, Virchows Arch 434 (1999), 23-28.

[32] M. Nakamura, N. Konishi, S. Tsunoda, Y. Tsunoda, Y. Hiasa, T. Tsuzuki, T. Inui and T. Sakaki, Retinoblastoma protein expression and MIB-1 correlate with survival of patiens with malignant Astrocytoma, Cancer 80 (1997), 242-249.

[33] T.H. Niemann, A.G. Yilmaz, V.R. McGaughy and L. Vaccarello, Retinoblastoma protein expression in endometrial hyperplasia and carcinoma, Gynecol Oncol 65 (1997), 232-236.

[34] K. Niwa, T. Murase, S. Morishita, M. Hashimoto, N. Itoh and T. Tamaya, p53 overexpression and mutation in endometrial carcinoma: inverted relation with estrogen and progesterone receptor status, Cancer Detect Prev 23 (1999), 147-154.

[35] H. Sasano, J. Comerford, S.G. Silverberg and C.T. Garrett, An analysis of the retinoblastoma gene in human ovarian and endometrial carcinoma, Cancer 15 (1990), 2150-2154.

[36] A. Semczuk, R. Schneider-Stock, R. Miturski, D. Skomra, J. Tomaszewski, A. Roessner and J.A. Jakowicki, Rb protein expression in human endometrial carcinomas-an immunohistochemical study, Pathol Res Pract 196 (2000), 41-46.

[37] E. Shimizu, A. Coxon, G.A. Otterson, S.M. Steinberg, R.A. Kratzke, Y.W. Kim, J. Fedorko, H. Oie, B.E. Johnson, J.L. Mulshine, J.D. Minna, A.F. Gazdar and F.J. Kaye, RB protein status and clinical correlation from 171 cell lines representing lung cancer, extrapulmonary small cell carcinoma, and mesothelioma, Oncogene 9 (1994), 2441-2448.

[38] P. Strang, B. Nordstrom, S. Nilsson, R. Bergstrom and B. Tribukait, Mutant p53 protein as a predictor of survival in endometrial carcinoma, Eur J Cancer 32 (1996), 598-602.

[39] C.J. Sung, Y. Zheng, M.R. Quddus, X. Kang, Z.-F. Zhang, S.C. Lauchlan and W. Zheng, p53 as a significant prognostic marker in endometrial carcinoma, Int J Gynecol Cancer $\mathbf{1 0}$ (2000), 119-127.

[40] R.A. Weinberg, Tumour suppressor genes, Science 254 (1991), 1138-1146.

[41] B.O. Williams, L. Remington, D.M. Albert, S. Mukai, R.T. Bronson and T. Jacks, Cooperative tumorigenic effects of germline mutations in Rb and p53, Nat Genet 7 (1994), 480 484.

[42] H.J. Xu, P. Cairns, S.-X. Xu, M.A. Knowles and W.F. Benedict, Loss of $\mathrm{Rb}$ protein expression in primary bladder can- 
cer correlates with loss of heterozygosity at the Rb locus and tumor progression, Int J Cancer $\mathbf{5 3}$ (1993), 781-784.

[43] Y. Yaginuma, H. Katayama, K. Kawai, J.C. Duenas and M. Ishikawa, Analysis of the retinoblastoma gene in human endometrial carcinoma, Obstet Gynecol 87 (1996), 755-759.

[44] N. Yamauchi, A. Sakamoto, H. Uozaki, K. Iihara and R. Machinami, Immunohistochemical analysis of endometrial adenocarcinoma for bcl-2 and p53 in relation to expression of sex steroid receptor and proliferative activity, Int J Gynecol Pathol 15 (1996), 202-208.

[45] W. Zheng, P. Cao, M. Zheng, E.E. Kramerand and T. Godwin, p53 and bcl-2 expression in endometrial adenocarcinoma. Comparison of serous and endometrioid subtypes, Gynecol Oncol 61 (1996), 167-174. 


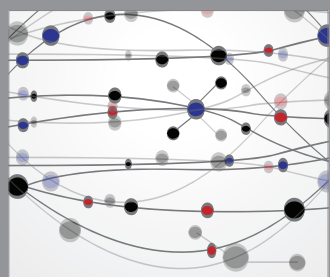

The Scientific World Journal
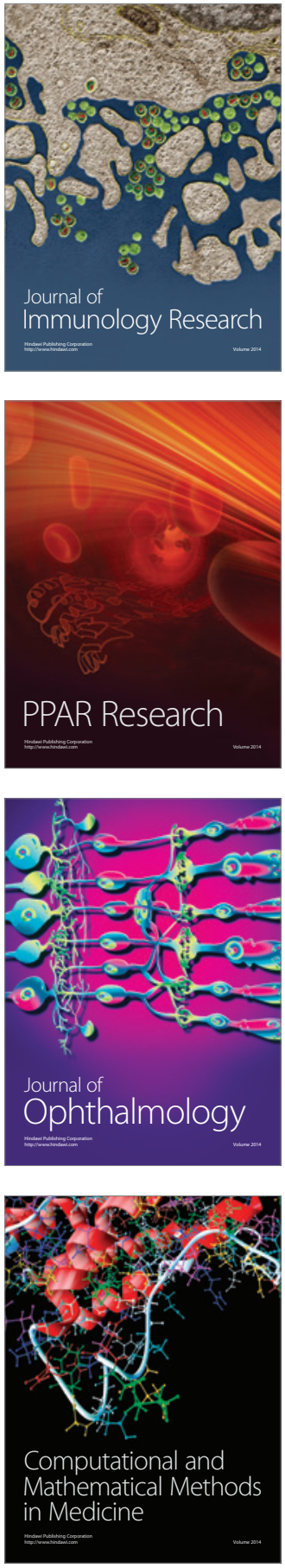

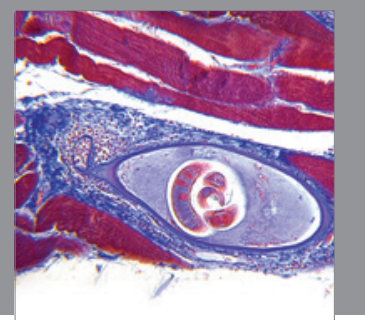

Gastroenterology

Research and Practice
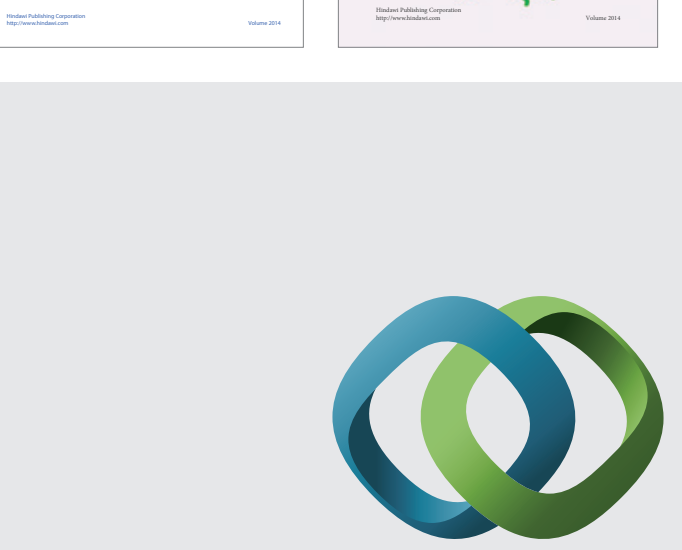

\section{Hindawi}

Submit your manuscripts at

http://www.hindawi.com
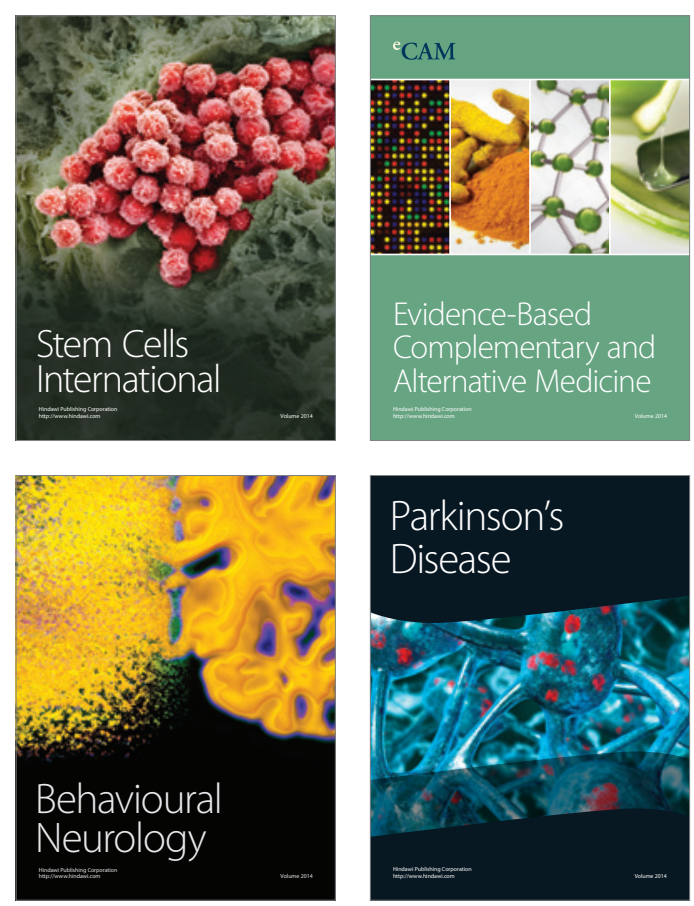

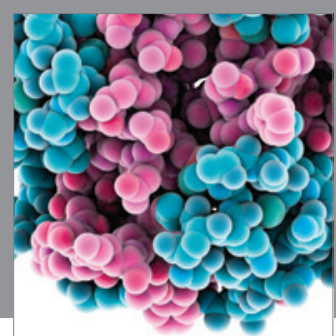

Journal of
Diabetes Research

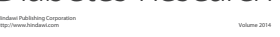

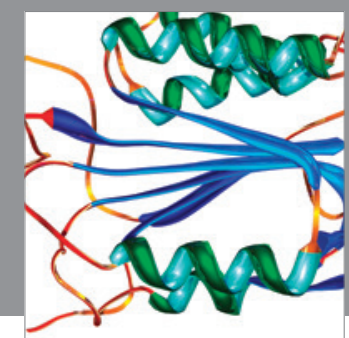

Disease Markers
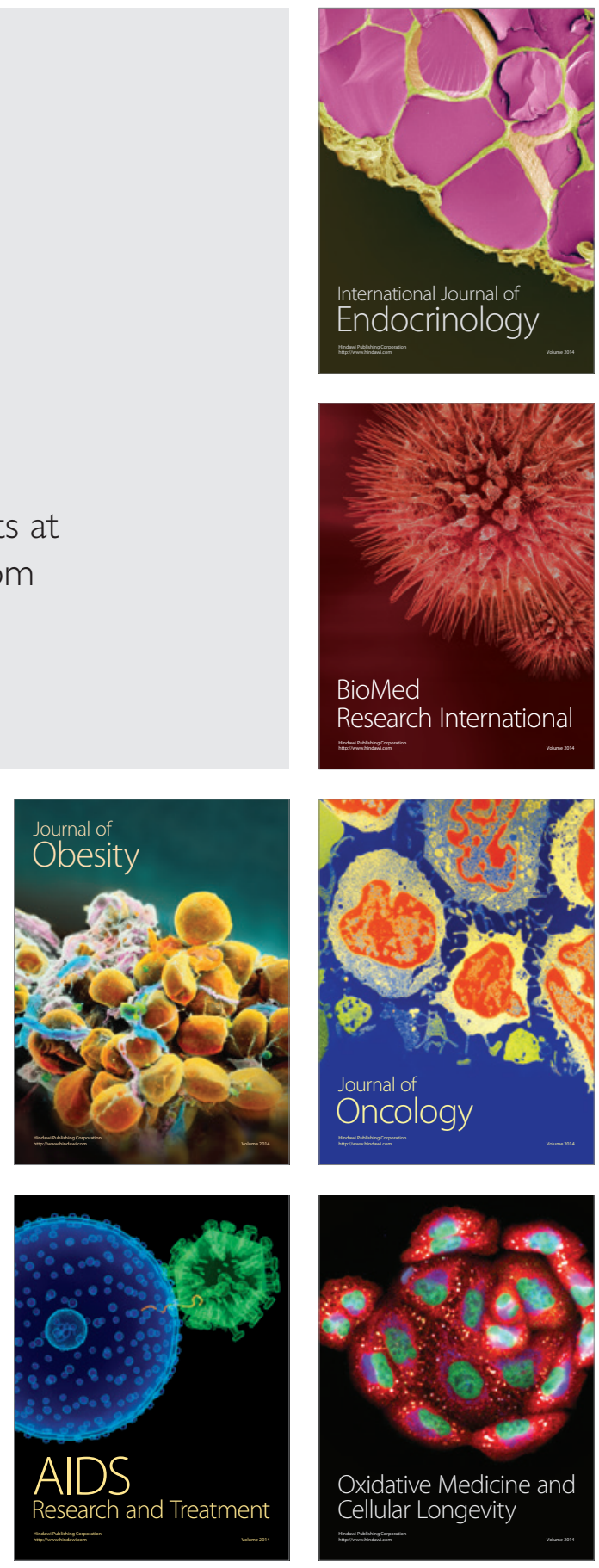